\title{
A realeza fenícia: um rei primus inter pares
}

\section{Phoenician royalty: a primus inter pares king}

\section{Realeza fenicia: un rey primus inter pares}

\author{
Maria Cristina Nicolau Kormikiari \\ Submetido em: 2-7-2021 \\ Aceito em: 5-8-2021
* Universidade de São Paulo Pós-doutora em Arqueologia E-mail: tanit@usp.br

\begin{abstract}
RESUMO
A Fenícia, região historiograficamente estabelecida, composta por cidades-estado mais e menos independentes, possuía, pelo que podemos depreender das fontes materiais e escritas que chegaram até nós, o estatuto da monarquia como forma de organização política. Neste artigo, apresentamos os dados compilados para as três maiores cidades fenícias, Biblos, Tiro e Sídon e discutimos a proposta do importante orientalista Maurice Sznycer acerca do estatuto da monarquia fenícia, que considerava o rei fenício um primus inter pares. Esta suposta divisão do poder é também analisada em relação à expansão fenícia pelo Mediterrâneo, notadamente em relação à fundação de Cartago.

Palavras-chave: Fenícia; monarquia; cidades-estado.
\end{abstract}

\begin{abstract}
Phoenicia, a historiographically established region, composed of more and less independent city-states, possessed, as far as we can infer from the material and written sources that have come down to us, the status of the monarchy as a form of political organization. In this article, we present the data compiled for the three largest Phoenician cities, Byblos, Tire and Sidon and discuss the proposal of the important orientalist Maurice Sznycer regarding the status of the Phoenician monarchy, which considered the Phoenician king a primus inter pares. This supposed division of power is also analyzed in relation to the Phoenician expansion across the Mediterranean, notably in relation to the founding of Carthage.
\end{abstract}

Keywords: Phoenicia; monarchy; city-sates.

\section{RESUMEN}

Fenicia, una región historiográficamente establecida, compuesta por ciudades-estado más y menos independientes, poseía, hasta donde podemos inferir de las fuentes materiales y escritas que nos han llegado, el estatus de la monarquía como forma de organización política. En este artículo, presentamos los datos recopilados para las tres ciudades fenicias más grandes, Biblos, Tiro y Sidón y discutimos la propuesta del importante orientalista Maurice Sznycer sobre el estatus de la monarquía fenicia, que consideraba al rey fenicio como un primus inter pares. Esta supuesta división de poderes también se analiza en relación con la expansión fenicia por el Mediterráneo, especialmente en relación con la fundación de Cartago.

Palabras clave: Fenicia; monarquía; ciudades-estados. 


\section{Introdução}

A Fenícia é usualmente compreendida como um território do Oriente Próximo, que abarca cidades-estado localizadas, arqueologicamente, entre o sul da atual Síria, na região de Tel Suqas, até o norte de Israel, região de Tel Dor. ${ }^{1}$ Quando olhamos para um mapa da chamada Fenícia (fig. 1), percebemos que as cidades fenícias se encontravam todas alocadas na costa deste território, ou seja, situadas em proximidade extrema ao mar.

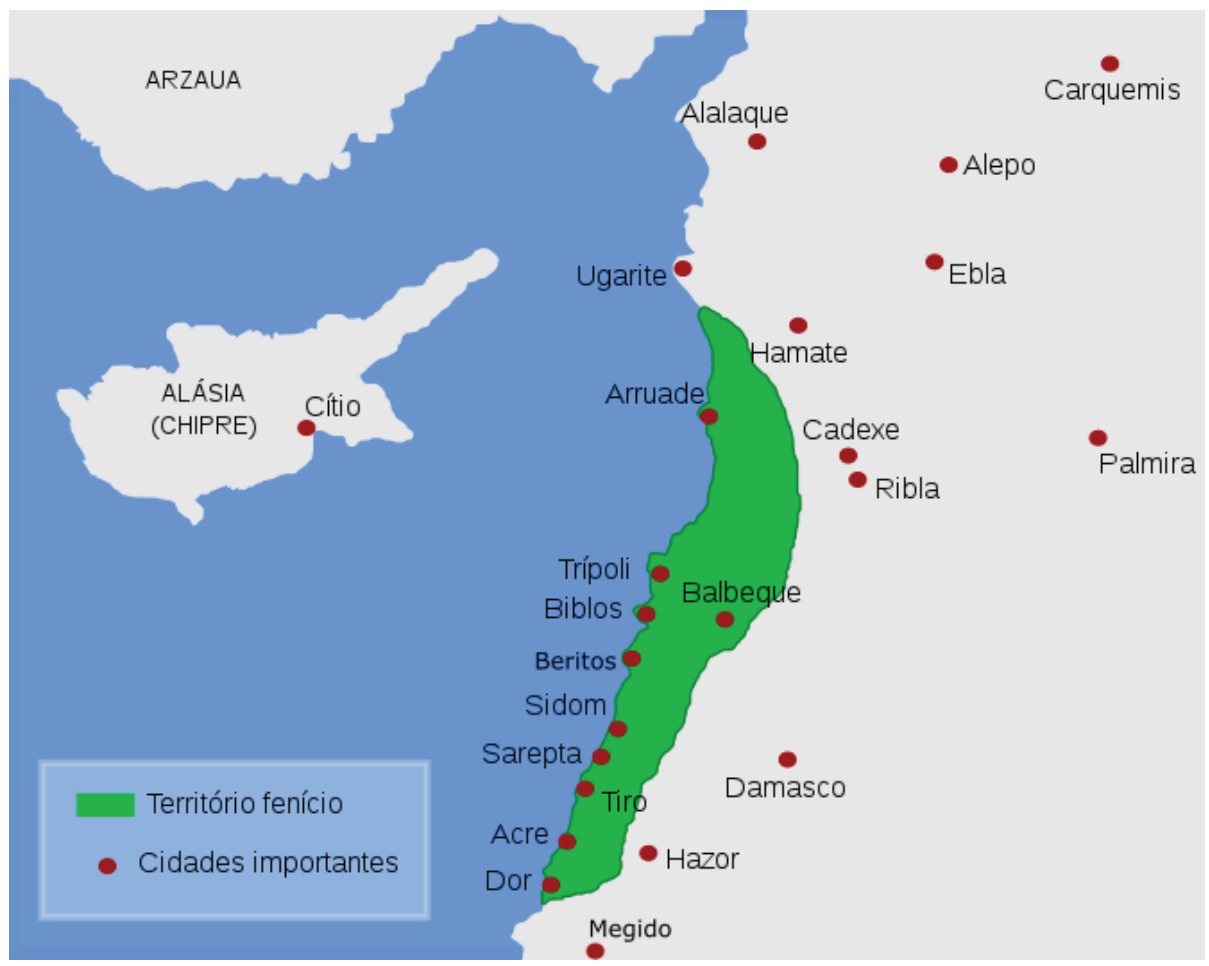

Figura 1: Mapa da Fenícia

Fonte: https://commons.wikimedia.org/wiki/File:Phoenicia_map-es.svg\#/media/

File:Phoenicia_map-pt.svg (Acesso em: 20/06/2021)

\footnotetext{
Seguindo Tamar Hodos (2020), entendemos cidade-estado como uma cidade nucleada e urbanizada, possuindo uma hinterlândia, graus diferenciados de autonomia política e econômica (a depender do período e do contexto local analisado), e relações comerciais, políticas e sociais com os territórios vizinhos. A partir do século VIII a.C., com o início da configuração da pólis grega, a qual deve ser entendida tanto como uma cidade-estado como enquanto um estado composto por seus cidadãos, os contatos já de há muito existentes com os fenícios devem ter contribuído para o desenvolvimento de expressões mais amplamente compartilhadas da urbanização que se formou e emergiu durante os séculos VII e VI a.C. em todo o Mediterrâneo. Para uma discussão historiográfica acerca do conceito de cidade antiga, ver KORMIKIARI, 2009.
} 
Um sítio fenício típico, tanto no Oriente Próximo, como as fundações coloniais pelo Mediterrâneo, ${ }^{2}$ costuma ser localizado seja em ilhotas próximas ao mar ou em promontórios e áreas costeiras, com a necessidade de bons portos sendo um fator constante. Chama atenção os casos de Útica, no Norte da África, e Castillo de Doña Blanca, na Espanha, os quais hoje em dia se encontram no interior, mas que estudos de paleoambiente demonstraram que, na Antiguidade, eram assentamentos costeiros (KALLALA et al., 2010; MATA, 2018).

A validade epistemológica do uso dos conceitos "Fenícia" e "fenícios" vem sendo posta em dúvida pela Academia nos últimos tempos. O mais recente questionamento veio do extenso estudo historiográfico de Josephine Crawley Quinn, no livro In Search of the Phoenicians, de 2018. Neste, a autora, historiadora da Antiguidade, retoma minuciosamente o percurso de construção da ideia de "fenícios", desde a Antiguidade até os dias atuais, pois não temos documentação escrita fenícia que nos remeta a um nome comum - fenício é um termo grego - nem à ideia de uma identidade conjunta.

No entanto, é preciso termos em mente que este importante questionamento, ao qual acrescentamos outras perguntas, como: podemos entendê-los

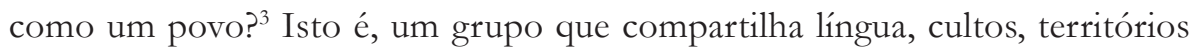
e uma história (cf. MOSCATI, 1974)? Ou ainda, teriam eles sempre estado na costa da Siro-palestina? E, então, neste sentido, seriam autóctones? Ou não, teriam vindo de outra(s) região(ões)? Se sim, de onde e quando? Enfim, estas são questões importantes e, de fato, têm sido tratadas com muito cuidado pelos estudiosos desde a década de 1960 do século XX (nota de rodapé número 3). Na mais recente obra de síntese, editada por dois grandes pesquisadores, Carolina López-Ruiz e Brian Doak, o Oxford Handbook of The Phoenician and Punic Mediterranean, de 2019, diversos capítulos abordam as questões mencionadas acima.

Ao mesmo tempo, podemos, sim, retomando tanto trabalhos clássicos como os artigos e capítulos de Sabatino Moscati (por exemplo, 1974), Maria Eugenia Aubet (2001), e as mais recentes sínteses (KILLEBREW, 2019; KORMIKIARI, 2019) compreender os fenícios como habitantes cananeus

\footnotetext{
2 O processo de fundação de novas cidades pelo Mediterrâneo pelos fenícios se coloca, cronologicamente, a partir dos séculos IX a.C. (KORMIKIARI, 1993; 2018). O caráter desse processo, no entanto, vem sendo bastante debatido nos últimos anos (cf. VAN DOMMELEN, 2012) pois se questiona o que podemos entender como colonização em relação à Antiguidade Mediterrânica. Neste sentido, em referência à Grécia, por exemplo, para a qual possuímos o termo êmico utilizado para nomear essas fundações além-mar, apoikia, seu significado literal é bastante interessante: “a casa - oikos - longe de casa” (cf. Glossário Labeca em http://labeca.mae.usp.br/pt-br/glossary/).

3 Para uma recapitulação do tema ver KORMIKIARI, 2019.
} 
da costa siro-palestina, os quais, diante do conjunto de movimentações populacionais, denominadas historiograficamente como invasões dos povos do mar, ${ }^{4}$ que alteram fortemente as configurações sociopolíticas da região na virada da Idade do Bronze e início da Idade do Ferro (c. 1200-1000 a.C.), se fecham em suas cidades-estado costeiras, reafirmando traços culturais compartilhados de há milênios. ${ }^{5}$

Do ponto de vista da cronologia, a Idade do Ferro I (entre 1200 a.C. e 900 a.C.) termina com a ascensão do império neoassírio e o início de sua expansão em direção aos territórios dos semitas ocidentais; a Idade do Ferro II (entre 900 a.C. e 539 a.C.) vai um pouco além da queda do império neo-babilônico; e a Idade do Ferro III (entre 539 a.C. e 332 a.C.) tem início com a ascensão do império aquemênida e termina com a conquista das cidades fenícias por Alexandre, o grande em 332 a.C. (cf. SADER, 2019a, p. 126).

Isto posto, as cidades fenícias orientais, a partir das fontes documentais textuais e arqueológicas são compreendidas como unidades monárquicas. ${ }^{6}$ A monarquia é um sistema político estabelecido, segundo as fontes textuais, há séculos, em cidades como Biblos e Tiro, por exemplo. Ou seja, os centros que denominaremos fenícios a partir do final da Idade do Bronze, séculos XII-XI a.C., irão, aparentemente, manter um sistema político pré-existente (DUNAND, 1973; ELAYI, 2014; GUIRGUIS; IBBA, 2017). ${ }^{7}$ Como assinalamos acima, admite-se uma continuidade cultural entre essas comunidades (PEDRAZZI, 2012; BONDİ, 2011), ${ }^{8}$ ainda que os pesquisadores, mais recentemente, venham advogando pela "divisão"

4 Sobre esta espinhosa questão relacionada ao fim da Idade do Bronze no Oriente Próximo existe uma vasta bibliografia, fortemente alimentada, nas últimas décadas, pelos avanços da pesquisa arqueológica. Sobre o tema, ver: KANIEWSKI et al., 2015 e FINKELSTEIN et al., 2017; para uma visão mais geral: BLOCH-SMITH; NAKHAI, 1999.

5 Para uma proposta contrária ver VAN DONGEN, 2010.

6 O mesmo, aparentemente, não acontece com as fundações mediterrânicas ocidentais, o que coloca questões historiográficas muito interessantes em relação a esse processo, a seus agentes e etapas. Sobre esta questão ver KORMIKIARI, 1993; AUBET, 2001; WAGNER, 2000; ALVAR EZQUERRA, 2008.

Em um estudo sobre um rei de Biblos, Rib-Hadda, que teria vivido em torno de 1350 a.C., a partir de 70 cartas (corpus documental de El Amarna) que chegaram até nós, dele para os faraós do Egito Amenhotep III e Amenhotep IV/Akhenaton (1353-1336 a.C.), enviadas ao longo de cerca doze anos, Josette Elayi (2014, p. 378) define Rib-Hadda como "rei” (šarru) para seus concidadãos mas, aos olhos da administração egípcia, ele seria um hazannu, termo que segundo a autora seria de difícil tradução mas que poderia se enquadrar em uma figura de "governador", "prefeito" ou "responsável local". Neste artigo, Josette Elayi grafa "Rei", com maiúscula, para se referir ao faraó egípcio, e "rei", com minúscula, para se referir "aos pequenos reis do Oriente-Próximo" (idem).

8 Percebida na cultura material das cidades, em seu panteão religioso, na língua e na organização política a partir do estatuto monárquico. 
da Fenícia em Fenícia Setentrional, com foco em Biblos e Arwad, e aproximação com o atual território sírio; e Fenícia Meridional, com foco em Tiro e Sídon, e aproximação com o atual território israelense, como veremos em detalhes abaixo.

Neste artigo vamos tratar acerca dessa monarquia fenícia. No entanto, a falta de uma documentação textual mais extensa nos impede de traçar linhagens reais completas para a maioria das cidades-estado fenícias. Possuímos algum material para Tiro, Biblos e Sídon, mas este é absolutamente fragmentado.

Ainda assim, a partir desta documentação, o historiador Maurice Sznycer (1984) definiu a realeza fenícia como uma realeza primus inter pares. Retomamos e apresentamos aqui este conceito.

\section{Sobre a realeza fenícia: visão geral a partir da documentação}

A primeira grande dificuldade com relação a uma reconstrução histórica acerca dos fenícios está diretamente ligada à falta de documentação textual. Há falta de estelas, epigrafia com inscrições reais, textos cotidianos, como contratos, e textos religiosos (BUNNENS, 2019, p. 57).

Não significa que não possuamos documentação textual em relação aos fenícios, afinal tendo sido eles os grandes propagadores do alfabeto, teríamos aqui uma grande ironia, mas esta documentação, por várias razões distintas, chegou até nós fragmentada e em relativo pequeno número. ${ }^{9}$ Por outro lado, a maioria da documentação textual existente é estrangeira, isto é, de povos com quem os fenícios mantiveram relações. Por exemplo, inscrições assírias reais e o Antigo Testamento, são fontes importantes, mas também há material nos textos clássicos.

\footnotetext{
Em termos textuais, temos menções e reproduções de autores fenícios e cartagineses em textos gregos e latinos. Já o grosso da documentação escrita direta é epigráfica, ou seja, escrita grafada em suportes materiais como pedra, cerâmica e madeira. E mesmo em relação a esse material, a imensa maioria vem de Cartago. São mais de 10.000 inscrições, majoritariamente relacionadas ao tofet - santuário a céu aberto dedicado às divindades Baal Hammon e Tanit Pene Baal - cartaginês. Na opinião de Josette Elayi (2007), inscrições monumentais mencionando reis datadas pelo ano de seus reinados existiram, mas foram destruídas ao longo do tempo em fornos de cal. Por outro lado, o estudo das cunhagens fenícias tem trazido importante documentação para os séculos V a.C. em diante. Ver, por exemplo: ELAYI; ELAYI, 1988.

É preciso ressaltar, ainda, documentação epigráfica em fenício (muitas vezes bilíngue com o luvita), datada dos séculos IX-VIII a.C., encontrada na região ao norte do Oriente Próximo, na Cilícia, a qual é fonte de debates acerca do porquê encontramos essa documentação tão distante das cidades fenícias do Levante. Como resume Frederick M. Fales (2017, p.195): "Por que o fenício foi adotado como uma língua de prestígio nesta área em particular, um tanto afastada de sua área natal? Será que seu status deriva de um avanço socioeconômico e/ou cultural explicitamente direcionado?” (tradução livre nossa).
} 
Interessantemente, os egípcios, com quem os fenícios mantiveram relações estreitas, raramente os mencionam em seus registros (BUNNENS, 2019, p. 57). ${ }^{10}$ A documentação assíria leva à inferência que as cidades fenícias formavam dois conglomerados: um Setentrional, incluindo a região que ia de Arwad a Biblos, cujas cidades se associavam a centros setentrionais da costa Síria, por exemplo, Usnu/Usnatu e Siannu; e um Meridional, que incluía Tiro e Sídon e alcançava a região meridional até Akko (BUNNENS, 2019, p.58).

Alguns autores vêm apontando como uma questão topográfica não deve ser desconsiderada em relação à formação destes dois "blocos". Assim, G. Bunnens (2019) e Iamoni (2019) acreditam que o Monte Líbano teve um papel importante nesta configuração, pois ao mesmo tempo que protegia a costa fenícia de incursões orientais, cortava esta, já que muitas vezes a cadeia se estende até a praia, criando promontórios, e literalmente, cortando o caminho.

O acesso à Fenícia Setentrional era através do Gap de Homs, uma passagem plana no vale do rio Orontes, no sul da Síria; e através da Planície de Akkar, entre a Síria e o Líbano. Já em relação à Fenícia Meridional, o acesso se dava pelo vale do rio Jordão, longa depressão que se estende por Israel, Jordânia, Cisjordânia e chega ao sopé dos Montes Golan, e pela planície de Jezreel, também conhecido como Vale de Meggido, pois este importante sítio está situado nesta região do interior setentrional de Israel (BUNNENS, 2019, p. 58).

Isto posto, nos valemos majoritariamente das fontes assírias, do Antigo Testamento (a Bíblia Hebraica), e de passagens de Flávio Josefo, ${ }^{11}$ além de alguma documentação epigráfica e material fenícias para tentar reconstruir as linhagens reais e as características destas monarquias.

\section{As cidades}

Temos, infelizmente, pouca documentação para nos informar acerca do desenvolvimento histórico individual das cidades fenícias. Ainda assim, é possível resgatar alguns nomes reais, que confirmariam a existência da instituição monárquica nessas cidades. Como veremos a seguir, em razão da fragmentação cronológica desta documentação, o que acabamos conseguindo são alguns momentos mais iluminados do que outros.

\footnotetext{
10 Para uma boa tentativa de reconstrução histórica dos fenícios ver SADER, 2019b.

11 Josefo alega ter consultado os arquivos de Tiro: Há, então, entre os tírios, escritos que abarcam muitos anos, escritos publicamente e muito bem guardados (SCHMITZ, 2019, p. 11, tradução nossa). Acerca do texto de Flávio Josefo, muito posterior, e à sua alegação de ter se baseado nos Anais de Tiro, serem críveis, ver KOKKINOS, 2013.
} 


\section{Biblos}

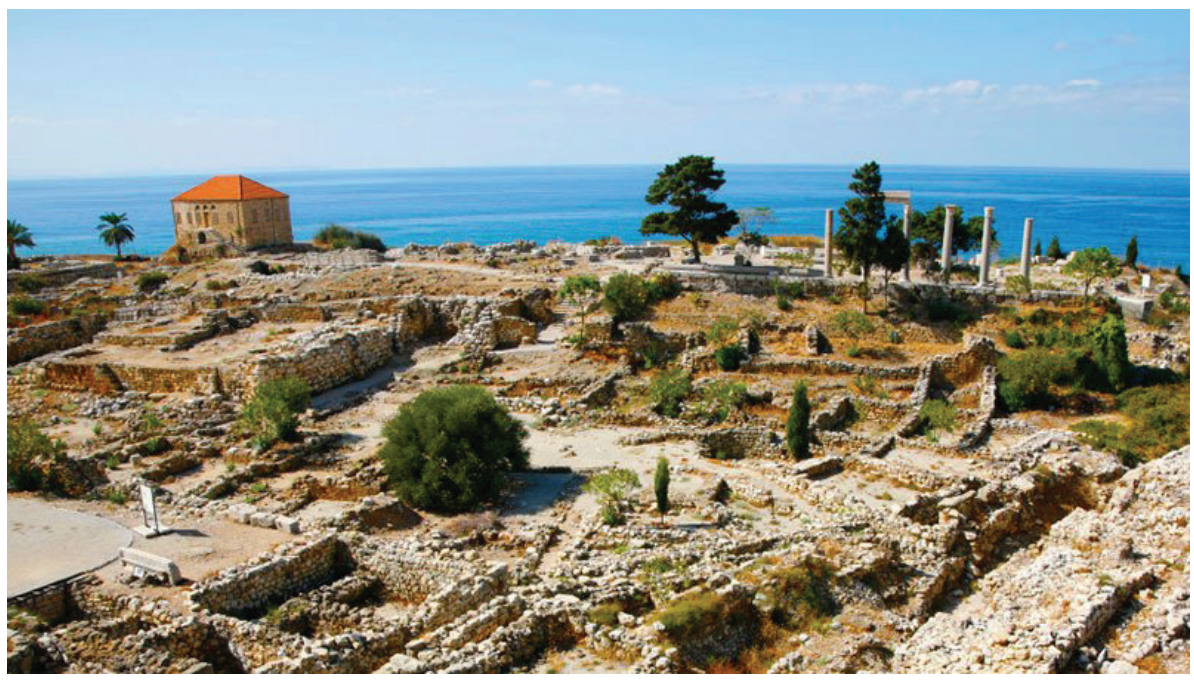

Figura 2: O sítio arqueológico de Biblos sobre um promontório.

Podemos ver diferentes camadas culturais de vestígios

materiais se sobrepondo ao longo do tempo.

Fonte: https://www.egypt-uncovered.com/tour/from-beirut-to-byblos-tour\#tourgallery $\% 20-6$

(Acesso em: 20/06/2021)

Biblos, no estado atual das pesquisas arqueológicas, é identificado como o assentamento mais antigo dentre as posteriores cidades-estado fenícias (Fig. 2). Segundo Moscati (1992, p. 23), já no III ${ }^{\circ}$ milênio a.C., Biblos apresenta evidências de autonomia, com documentação material que reencontraremos nas futuras cidades fenícias.

A primeira referência que possuímos em relação à monarquia na Biblos fenícia aparece no relato, datado do século XI a.C. e contido em um papiro egípcio, do enviado egípcio do supremo sacerdote de Ammon, denominado Ounamon, daí este ser comumente referido como "relato de Ounamon". ${ }^{12}$ O mesmo nos conta das inúmeras peripécias pelas quais passou nosso infeliz personagem em sua saga para garantir o cedro, a madeira fenícia por excelência, necessária para a construção do barco sagrado do deus egípcio. O rei de Biblos com quem Ounamon tentará negociar é denominado Shekerbaal. O rei,

12 A História de Ounamon (conhecido como Misadventures of Ounamon ou simplesmente Ounamon) é um texto egípcio escrito em escrita hierática. Este texto é conhecido apenas por uma cópia incompleta, encontrada em 1890 em El Hibeh, no Egito. Comprada no Cairo pelo egiptólogo russo Vladimir Semenovich Golenichtchev (CAMINOS, 1977), o papiro é agora preservado na coleção do Museu de Belas Artes Pushkin, Moscou, e oficialmente intitulado "Papyrus hiératique tardif Pouchkine numéro 120". 
inicialmente, se recusa veementemente em receber o enviado egípcio, pois o protocolo de reconhecimento não havia sido realizado, ou seja, os presentes diplomáticos - que podemos conceituar como fazendo parte do sistema de dom e contra-dom elaborado por Marcel Mauss na seminal obra Ensaio sobre o dom. Forma e razão da troca nas sociedades arcaicas (1974) - não haviam sido entregues. Após este obstáculo ser superado, Shekerbaal apresenta-se como o detentor do poder na região: "Se eu der um grito em direção ao Líbano, faço o céu se abrir e os troncos chegarão aqui e o príncipe [...] envia 300 homens e 300 bois, colocando à sua frente mensageiros, para que os troncos sejam cortados" (BONDİ, 1995, p. 270; KORMIKIARI, 2004, p. 133).

Mais adiante no tempo, possuímos alguma evidência epigráfica do século $\mathrm{X}$ a.C., a qual permite que seja traçada duas sequências dinásticas. A primeira inscrição é a mais famosa: o sarcófago de Ahiram (KAI 1; apud BUNNENS, 2019, p. 58). Esta nos dá a seguinte sequência, datada do século X a.C., em razão da paleografia:

1. Ahiram

2. Ito-Baal (ou Pilsi-Baal)

A segunda sequência dinástica nos é apresentada por quatro inscrições:

3. Yehi-Milk $(K A I$ 4)

4. Abi-Baal (KAI 5)

5. Eli-Baal (KAI 6)

6. Shipit-Baal (KAI 7)

A datação é feita a partir dos objetos nos quais duas das inscrições aparecem: estátuas de faraós egípcios. A de Abi-Baal está em uma estátua de Sheshonq I (945-924 a.C.) e a de Eli-Baal, em uma estátua de Osorkon I (924-889 a.C.). Segundo Bunnens (2019, p.58), as inscrições devem ter sido feitas logo da subida ao poder destes faraós; portanto, pertencem, também, à segunda metade do século $\mathrm{X}$ a.C.

As seis inscrições apresentadas acima representam as mais antigas escritas de Biblos. Existe, na verdade, um debate acerca dessa cronologia. Houve uma tentativa de se levar a datação um século adiante, isto é, entre 850 e 750 a.C., mas a documentação em fenício do norte da Síria, datada de 825 a.C., traz inovações paleográficas que determinam, assim, a manutenção das inscrições de Biblos no horizonte do século X a.C., por terem uma escrita mais arcaica (FALES, 2017, p. 190).

De interesse ao tema de nosso artigo, entretanto, é a análise da reutilização das estátuas de dois faraós por reis fenícios. Se admitimos, conforme 
assinalado acima, que cada estátua recebeu imediatamente a re-inscrição com os nomes dos dois reis de Biblos, isto pode significar uma mudança de "tendência" ideológica, assinalando o fim de um longo processo de transferência de estátuas de faraós para o Levante contando com uma recepção reverente destas. Assim: “...pela primeira vez, príncipes de Biblos ousaram tomar posse de estátuas daqueles que haviam sido seus mestres em uma época que não mais existia" (MATTHIAE, 2000, p. 193 apud FALES, 2017, p.190 - tradução livre nossa).

Uma nota precisa ser feita em relação a Ahiram e seu sarcófago e a inscrição em fenício (Fig. 3). A inscrição fenícia no sarcófago de Ahiram, de Biblos, foi descoberta em 1923 por Pierre Montet gravada sobre a tampa do "superbo sarcófago". Este, por sua conta, estava na câmara funerária no fundo do hipogeu $\mathrm{V}$ do sítio de Biblos. Logo de sua descoberta foi considerada a inscrição em fenício mais antiga já encontrada. Como coloca a arqueóloga Adriana Ramazzina (2012, p.163):

Após um longo debate relacionado à tumba de Ahiram, chegou-se à conclusão que ela pode ser datada de cerca de 1000 a.C. Foi escavada em 1923, junto a outras oito tumbas, todas em câmara escavadas na rocha com acesso em poço, na acrópole. A tumba $\mathrm{V}$ continha três sarcófagos monolíticos, todos violados. O sarcófago de Ahiram ${ }^{13}$ é o mais antigo e célebre sarcófago fenício... Tem a forma de paralelepípedo e é todo decorado, inclusive sua tampa. Há cenas de procissão nos lados longos, e carpideiras nos lados curtos. Na tampa há dois leões e duas figuras humanas que portam uma flor de lótus (Moscati, 1997, p.355) cada. Além da inscrição em fenício na tampa do sarcófago, em nome do filho de Ahiram, há outra na parede superior do poço de acesso à câmara funerária com mensagem de aviso aos profanadores. O último enterramento da tumba $\mathrm{V}$ é datado do séc. IX, e entre os objetos mais antigos encontrados, há um vaso de alabastro com o nome de Ramsés II (1301-1234 a.C.) (CIASCA, 1997, p. 173).

\section{Tiro}

A partir das pesquisas arqueológicas, admite-se que a maioria dos centros fenícios eram de pequeno porte, com cerca 3 ha de tamanho. A exceção é Tiro, cuja extensão das áreas escavadas na ilha onde se encontra o sítio principal permite aos arqueólogos estimarem um tamanho de 16 ha (Fig. 4) (SADER, 2019, p.128).

\footnotetext{
13 O Museu de Arqueologia e Etnologia da Universidade de São Paulo possui uma cópia em gesso deste sarcófago, presente do governo do Líbano na década de 1960.
} 


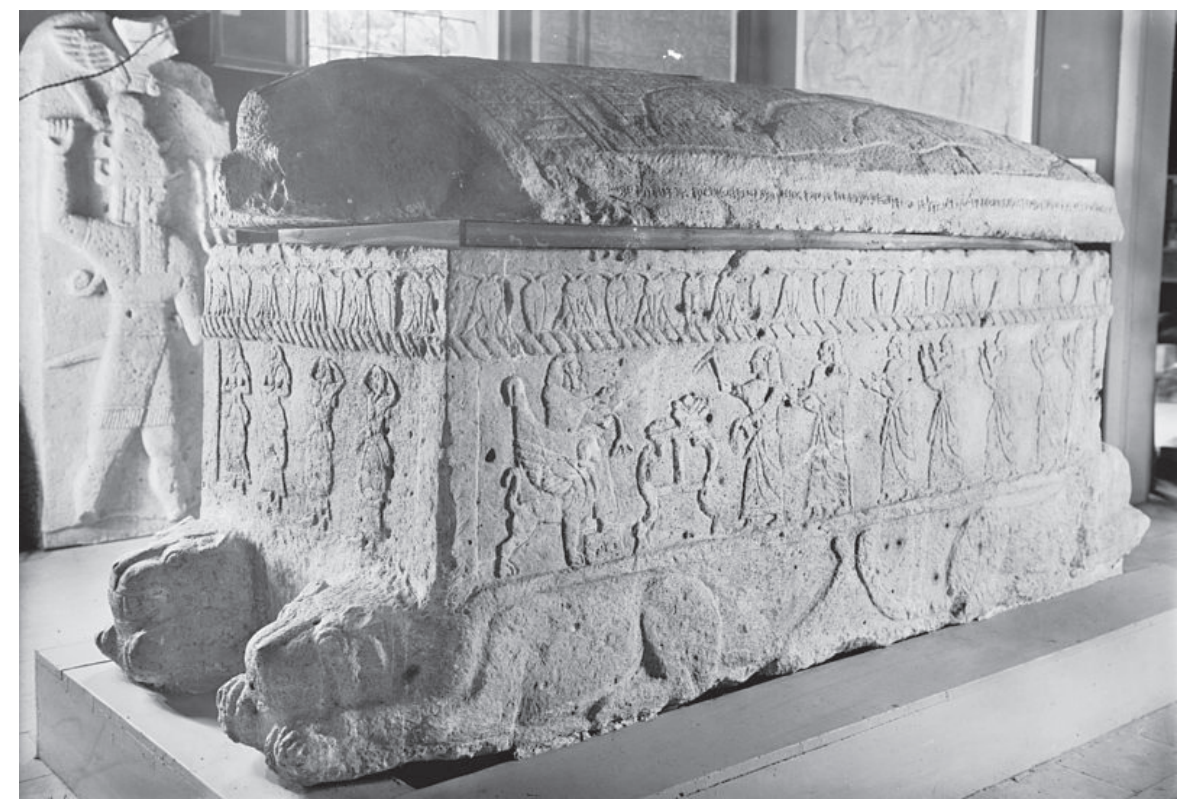

Figura 3: Sarcófago de Ahiram, século X a.C.

Fonte: https://ar.m.wikipedia.org/wiki/\%D $\% \% 85 \%$ D $9 \% 84 \%$ D $\% \% 81$ :Ahiram_ sarcophag_from_Biblos_XIII-XBC.jpg (Acesso em 10/06/20201)

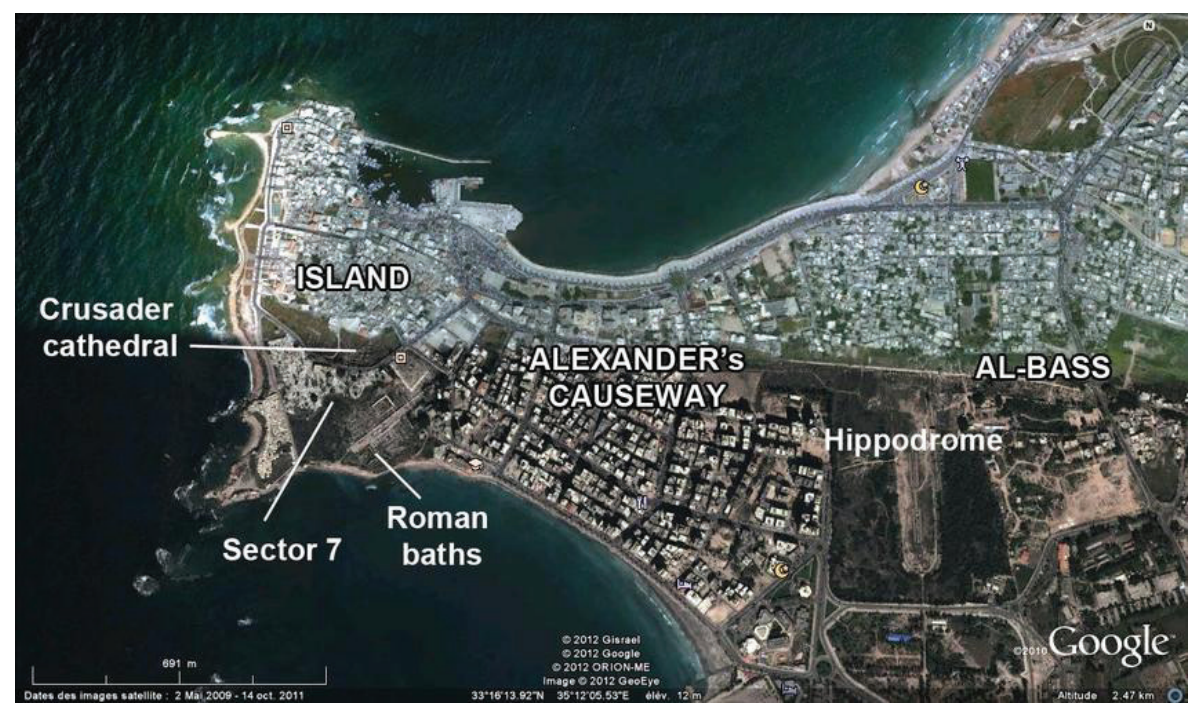

Figura 4: Vista aérea do sítio arqueológico de Tiro e da área moderna da cidade atual. A ilhota da cidade antiga, em razão da ação de Alexandre, o grande, por ocasião do sítio e conquista da mesma no século IV a.C., e dos subsequentes processos geomorfológicos, encontra-se, hoje, ligada ao continente. No alto, à esq., vemos a acrópole da cidade antiga, originalmente na ilhota, e à dir. vemos a necrópole de Al-Bass, no continente, marcando um dos limites da cidade. Fonte: BOSCHLOOS, 2016. 
No entanto, Tiro, em sendo um típico assentamento fenício, possuía uma cidade alta (fortificada), no caso, localizada na ilha, e uma cidade baixa se estendendo pela hinterlândia, no continente. Os limites das cidades fenícias eram marcados pelo mundo dos mortos, pelas necrópoles (SADER, 2019, p. 128). Tiro seria, pois, composta por duas áreas, a ilhota próxima à costa e o território se estendendo pelo continente. No lado leste da ilhota haveria uma esplanada, denominada evrychoros, local do mercado, das trocas. ${ }^{14}$

Em relação a esta importante cidade, o período histórico mais conhecido é também o séc. X a.C., sob Abibaal e Hiram I (962-929 a.C.) (GUIRGUIS; IBBA, 2017, p. 193). Nossa documentação vem do relato de Flávio Josefo (Ant., 8: 145). Segundo esse autor, suas informações vieram de dois autores anteriores: Menandro de Éfeso (provavelmente escrevendo no século II a.C.) e Dios, de data desconhecida ( $A J$ 8.144-46 e $A p$. 1.117-19 a partir de Menandro; $A J 8.147$ e $A$ p. 1.113 a partir de Dios apud BUNNENS, 2019, p. 59).

Bastante mencionada nas reconstruções hipotéticas da cidade de Tiro, seria a já mencionada esplanada, a qual teria sido construída a mando de Hiram I para conectar a área da cidade alta de Tiro com a área na qual estava localizada o templo de Zeus Olímpio (provavelmente Baal Shamim), decorado com oferendas de ouro e/ou um pilar de ouro (Fig. 5).
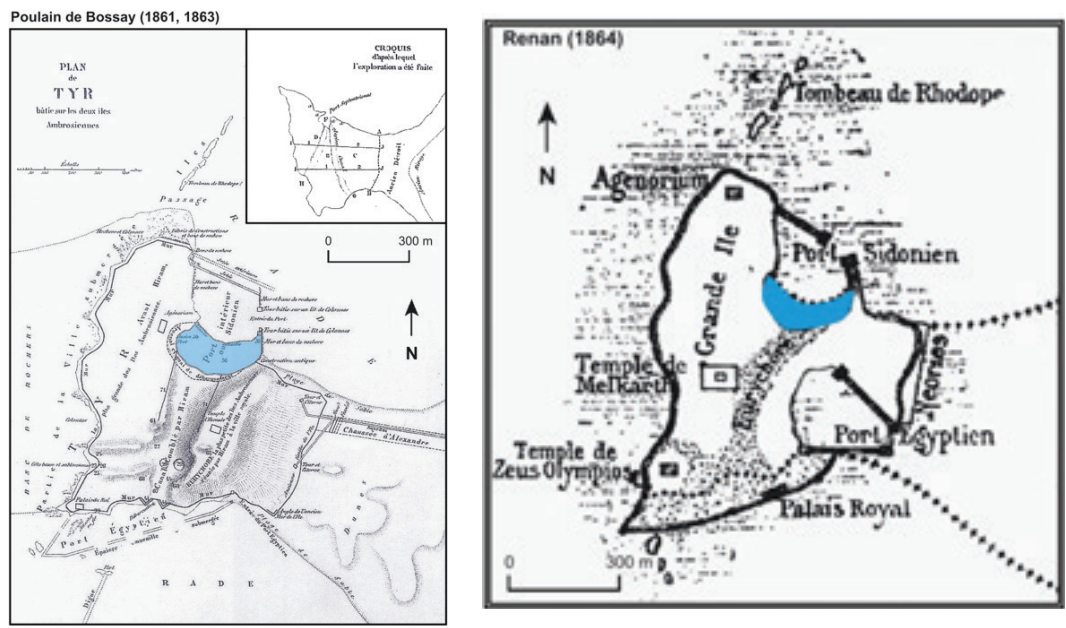

Figura 5: Localização hipotética da esplanada evrychoros (marcada pelo círculo azul) na ilha de Tiro, a partir de trabalhos arqueológicos do século XIX.

Fonte: MARRINER; MORHANGE; CARAYON, 2008, p. 1283.

\footnotetext{
14 O profeta Ezequiel (27: 1-36), em sua narrativa acerca dos circuitos comerciais de Tiro, menciona o grande mercado da cidade, evrychoros, o qual deve ser localizado próximo ao porto setentrional da cidade alta. Tiro possuía quatro portos, os dois principais eram o setentrional em direção a Sidon, e o meridional em direção ao Egito (MARINER; MORHANGE; CARAYON, 2018, p. 1282). Sobre os circuitos de atuação econômica de Tiro ver LIVERANI, 2004.
} 
Dentro da obra de urbanização de Tiro, Hiram I também teria demolido os antigos santuários de Melqart e Astarte, e mandado trazer do Monte Líbano cedro para cobrir os novos templos que ele mandou dedicar a estes mesmos deuses. ${ }^{15}$

De fato, o culto a Melqart é bastante estudado (BONNET, 1989) e esta divindade é interpretada como uma "novidade", relacionada a esse novo momento de conformação de uma identidade fenícia, e de sistematização das cidades-estado. Seu nome tem o significado de "rei da cidade" (MLKQART), e, neste sentido, seria a garantidora da realeza. Assim, não espanta a notícia que Hiram I teria promovido o culto a Melqart não apenas mandando construir um novo templo para a divindade, mas, principalmente, instituindo a celebração da grande cerimônia do "despertar" do deus (égersis).

Josefo (AJ 8.324, a partir de Menandro) relata que o rei Itto-Baal teria fundado no século IX a.C. uma cidade, Botrys (moderna Batroun), ao norte de Biblos (BUNNENS, 2019, p. 59). Igualmente, Josefo reproduziu duas listas de reis tírios, ambas emprestadas de Menandro. A primeira, lista os reis que governaram nos séculos X e IX a.C. (Ap. 1.116-26); a segunda, reis da primeira metade do séc. VI a.C. (Ap. 1.115-60). ${ }^{16}$

Josette Elayi (2013, p. 213-30 apud GUIRGUIS; IBBA, 2017, p. 193) reconstrói os eventos que teriam levado à interrupção forçada, e posterior restauração, da linha monárquica em Tiro em favor de uma nova organização administrativa, o sufetato, ${ }^{17}$ no século VI a.C. Assim, em 573 a.C., após 30 anos de ataques do exército de Nabucodonosor II (605-562 a.C.), o rei tírio Itobaal III (c. 591-572 a.C.) cai - tendo sido deportado para a Babilônia - e sobe ao poder um soberano fiel aos babilônios. Este rei, Baal II, fica no poder entre 572 e 563 a.C., até ser, ele também, deportado para a Babilônia. Guirguis e Ibba (2017, p. 193) acreditam que a queda da monarquia em Tiro se dá em razão da intervenção política de Nabucodonosor II contra Baal II em 563 a.C., o que teria levado à instituição do sufetato nesta cidade fenícia.

Com a morte de Nabucodonosor II em 562 a.C., sobe ao poder na Babilônia seu filho, Amel-Marduk, que reinou por apenas dois anos. Seu sucessor teria permitido a restituição da monarquia em Tiro. Desta maneira, por volta de 556 a.C., e durante apenas um ano, sobe ao trono tírio Baalazor (III?), sobre quem não temos maiores informações, além do fato que um possível sucessor ter sido Maharbaal (c. 555-552 a.C.) (GUIRGUIS; IBBA, 2017, p. 194). Segundo Josette Elayi (2013, p. 324-25 apud GUIGUIS; IBBA, 2017, p. 194):

\footnotetext{
15 Alguns estudiosos, como Sandro Filippo Bondì (2013, p. 150) se colocam contrariamente a esta possibilidade, enquanto fato histórico, em razão da menção a uma reconstrução, ou seja, pressupondo a existência de templos anteriores dedicados a estas divindades. O problema seria em relação a Melqart, cujos cuidadosos estudos de Corinne Bonnet, bem demonstraram ser uma novidade no panteão, um "ancestral dos reis de Tiro, protótipo deste rei" (BONNET, 2004, p. 114).

16 Guy Bunnens (2019) alerta para alguns problemas destas listas, os textos estão corrompidos e oferecem um enquadramento cronológico grosseiro.

17 Sobre o sufetato falaremos mais adiante, quando discutiremos o exemplo de Cartago.
} 
...o rei babilônio dá seu aval quando, após o fim do reino de Maharbaal em 552, os tírios vão até a Babilônia procurar seu irmão, Hiram III, o qual reina por 20 anos, entre 551 e 532. Este longo reino se coloca entre o Império Babilônico e o Império Persa. Diversos indícios mostram que Tiro não é mais a cidade poderosa e próspera descrita nos oráculos de Ezequiel. [...] Tudo indica um enfraquecimento e um declínio desta cidade fenícia no final do Império babilônico. Para coroar tudo, Tiro teria sido vítima de um terremoto em torno de 550 a.C. (tradução livre nossa).

Antes desses eventos, no entanto, acredita-se que o grupo meridional formou um reino unido, Tiro e Sídon, por um certo tempo, provavelmente entre os séculos IX-VII a.C., a partir de três observações (BUNNENS, 2019, p. 59 e 60):

1. Tiro e Sídon, em grupo, mandam delegados para a inauguração do palácio de Assubarnipal II em Kalhu (RIMA 2, A.0.101.30, 143-47). Duas das faixas de bronze que decoravam os portões de Balawat, de Shalmaneser III, traziam a iconografia da entrega de tributos por povos que as epígrafes designam como tírios e sidonianos, e as imagens os mostram vindo de uma ilha, que só pode ser Tiro.

2. Fontes que mostram que o rei de Tiro possuía domínio sobre Sídon. O governador de Smirra, Qurdi-Assur-Iamur, registra para Tiglath-pileser III que Hiram cortou um objeto de culto em um templo de Sídon e o queria transportar para Tiro $(S A A 19$, n. 23). É o mesmo Hiram que aparece como rei de Tiro nas inscrições de Tiglath-pileser III (PNA 2/I, 474). Uma tigela, comprada em Limassol (Chipre), no século XIX, traz a inscrição "Hiram, rei dos sidônios" (KAI 31). Qurdi-Assur-Iamur acrescenta que Matenni, o provável sucessor de Hiram em Tiro (PNA 2/II:750), havia organizado a entrega do tributo, e coloca que todos os sidonianos deveriam vir e encontrá-lo para mandar o tributo para o rei $(S A A 19$, n.24).

Mais para frente, Sennacherib apresenta Lulli como rei de Sídon (PNA 2/II: 668-69), mas coloca que seus domínios se estendiam até Akko. Também menciona que Lulli tentou escapar de Tiro (RINAP 3/1, texto 46: 18-19) e, nos registros de suas campanhas, se vangloria por ter conquistado Tiro, sem mencionar Sídon (RINAP 3/1, texto 4: 15-17). Para Bunnens (2019, p. 60), apesar de Sídon aparecer à frente aqui, Tiro deveria continuar como líder, mas como Sennacherib não conquistou Tiro, ele dá prevalência a Sídon.

3. Por fim, haveria um argumentum ex silentio. Não temos documentação que ateste, sem dúvidas, a existência de qualquer rei de Sídon antes 
do séc. VII a.C., época de Esarhaddon, quando Abdi-Milkutti era rei de Sídon (PNA 1/I: 7).

A partir, pois, de 738 a.C., as fontes textuais nos contam de investidas muito agressivas por parte dos assírios visando o controle total da siro-palestina. ${ }^{18}$ Tiglath-pileser III (744-727 a.C.) submete as cidades da costa síria e da Fenícia Setentrional (Simirra e Arqa), colocando-as sob a tutela de um governador instalado em Simirra. Enquanto isso, Hiram II (736-729 a.C.), de Tiro, e Sibitti-Bi'il, de Biblos, pagavam tributo aos assírios (RINAP, Texto 14:11; Texto 27:3; Texto 32:2).

Temos a notícia de que Hiram II, que havia tentado se posicionar como aliado do rei de Damasco em 733/732 a.C., foi sitiado na ilha da cidade alta de Tiro e forçado à rendição (BUNNENS, 2019, p. 67). Mais à frente, temos a menção a um rei denominado Metenna (RINAP, 1, Texto 47: rev. 16). E um terceiro rei, Tuba'il (PNA 3/II, 1328) é mencionado por Tiglath-pileser, apesar de não podermos relacionar com exatidão sua posição na sequência dinástica (BUNNENS, 2019, p. 67). ${ }^{19}$

Sem dúvida, de todos os reis tírios dos quais temos alguma documentação, Hiram I é o mais conhecido. Hiram I talvez seja ainda mais famoso que Ahiram. Sua fama vem dos relatos no Antigo Testamento e de sua relação de amizade com Salomão. Na verdade, não possuímos fonte fenícia, textual ou material, que o mencione. Ainda assim, a fama de Hiram I está ligada ao processo de expansão fenícia pelo Mediterrâneo Central e Ocidental.

Duas atividades costumam ser relacionadas aos fenícios: navegações e trocas comerciais. ${ }^{20} \mathrm{~A}$ janela de maior ocorrência destas se enquadra entre os séculos XI e VII a.C. (GRAS; ROUILLARD; TEIXIDOR, 1988, p. 80). Se

18 Segundo F. M. Fales (2017, p. 184), as Inscrições Reais Assírias (Assyrian Royal Inscriptions) representando o registro oficial assírio, seriam os guias principais - junto a um conjunto "cotidiano" de documentos como cartas, textos legais e materiais divinatórios, todos em escrita cuneiforme - para a reconstrução histórica dos séculos VIII-VII a.C., especialmente entre os reinos de Tiglath-pileser III (745-727 a.C.) e Assurbanipal (668-631 a.C.), no que concerne a subjugação e a administração imperial do Levante (do Golfo de Iskenderun à região do Sinai). As Inscrições Reais Assírias costumam nomear os diferentes povos com quem e lugares onde os exércitos assírios contataram e passaram em sua expansão ocidental, e fornecem, igualmente, informação sobre o status dado aos diferentes assentamentos em seguida à conquista, seja como reinos clientes, forçados a pagar tributos anuais ainda que mantendo autonomia política, ou como províncias do Império em expansão.

19 Para uma tentativa de reconstrução das linhagens reais de Tiro, principalmente em relação ao período Aquemênida, ver ELAYI, 2007.

20 O debate acerca do conceito "economia antiga" é mais que secular, lidando com temas seminais como a emergência do mercado, sua conceituação e aplicação no tempo e no espaço (para uma visão ampla do tema, ver FLORENZANO, 2000). A invenção da moeda é passo importante neste processo, mas não decisório na análise da complexificação de uma dada sociedade. Os próprios fenícios, talvez os mais prestigiados comerciantes da Antiguidade, só emitirão cunhagens citadinas a partir do século V a.C. Em uma pesquisa muito instigante, Eleftheria Pappa (2019) advogou pela existência de uma economia de crédito, utilizando-se de documentos escritos, que teria facilitado a expansão comercial fenícia, entre os séculos IX e VII a.C., e a divulgação e adaptação ocidental do alfabeto fenício. 
no seu início, a conexão com o poder monárquico parece bem estabelecido, temos que, ao longo destes quatro séculos, o processo não pode ser considerado uniforme e estático. Claramente, temos que lidar com a existência de transformações sociais nas cidades fenícias, o que implica em transformações dos agentes da iniciativa comercial. Em se alterando os agentes, é de se postular modificações estruturais maiores, organizacionais. Igualmente, os chamados circuitos de atuação dos fenícios se modificaram, além dos produtos comercializados.

Ainda assim, pensando no primeiro momento desta expansão nos leva, conforme colocamos acima, a Hiram I. Cartago, a maior e mais poderosa fundação fenícia em terras mediterrânicas centro-ocidentais - o sítio está localizado modernamente na costa de Túnis, capital da Tunísia, no Norte da África - foi fundada, de acordo com os relatos textuais e materiais no século IX a.C. por tírios (KORMIKIARI, 2018, p. 178). ${ }^{21}$

Como bem coloca Sandro Filippo Bondì (2013, p. 150), a documentação acerca de Hiram I está ligada ao texto bíblico, que o relaciona com David (II Sam., 5, 11) e com Salomão (I Reis 5, 1-11; I Reis 9, 10-14, 26-28; I Reis 10, 11-22) e como assinalamos acima, constitui praticamente a documentação mais importante que temos acerca deste rei.

Hiram teria realizado um acordo (berît) com Salomão após uma troca de cartas para fornecer madeira fenícia - e Salomão faz questão de ressaltar a maestria fenícia na arte da carpintaria - para a construção do Templo "em nome do senhor", o templo de Jerusalém. Este acordo deve ser entendido como uma aliança, a qual funcionou em dois campos: o de fornecimento de madeira e mão de obra em troca de óleo e trigo; e o segundo, relacionado a navegações conjuntas (BONDİ, 2013, p. 150). ${ }^{22}$

Seguindo as menções no Antigo Testamento vemos reafirmadas as importantes e vitais trocas entre Tiro e o reino de Salomão, no século $\mathrm{X}$ a.C. ${ }^{23}$ : 1Rs 5,15-25 - Hiram envia prontamente madeira para a construção do templo e do palácio, em troca recebeu óleo e trigo; 1Rs 9,10-14 - Hiram envia 20 talentos de ouro para a decoração das construções e recebe de volta um distrito da província da Galiléia (terra de Kabul) - reclama que a terra

21 Seguindo Guy Bunnens (1979, p. 285) o sacerdócio de Melqart estaria envolvido, junto à realeza, com as primeiras empreitadas fenícias pelo Mediterrâneo. Assim, a partir de um relato de Diodoro Sículo (XX, 14: 2), vemos Cartago, em seu período inicial, enviando anualmente ao templo de Melqart em Tiro um décimo de sua riqueza. Na opinião de Bunnens, este valor seria mais que uma oferenda. Seria, de fato, o retorno de valores emprestados para a empreitada das navegações e fundação da capital africana.

22 Não temos espaço aqui para abordar um dos tópicos mais pesquisados acerca das relações entre hebreus e fenícios e suas empreitadas marítimas conjuntas, que envolvem a compreensão do termo Tarshish, atualmente mais provavelmente equacionado com uma localidade na costa do Mar Vermelho ou com a Cilícia. Sobre o tema, ver KORMIKIARI, 2004, p. 135.

23 Ainda que algumas destas notícias sejam desacreditadas (BUNNENS, 2019, p. 65). 
não tem valor; 1Rs 9,28; 10,11-12 - Hiram coloca à disposição de Salomão seus navios para irem ao "país de Ophir" (provavelmente na costa ocidental da Arábia) (KORMIKIARI, 2004).

Estes poucos exemplos nos dão notícia da importância estratégica das cidades fenícias durante a Idade do Ferro Inicial, o que ademais é atestado pelo expressivo conjunto de assentamentos além-mar que serão estabelecidos nos séculos seguintes.

No entanto, pesquisas mais recentes colocaram em dúvida a própria existência do reino de Salomão e David, apresentando-o como uma construção do século VII a.C. (FINKELSTEIN; SILBERMAN, 2002, p. 137-59 apud BUNNENS, 2013, p. 150). Seria possível postular que o aclamado reino de Hiram I igualmente devesse ser visto como uma construção ideal, que melhor caberia no mesmo século VII e não no IX a.C.?

\section{Sídon}

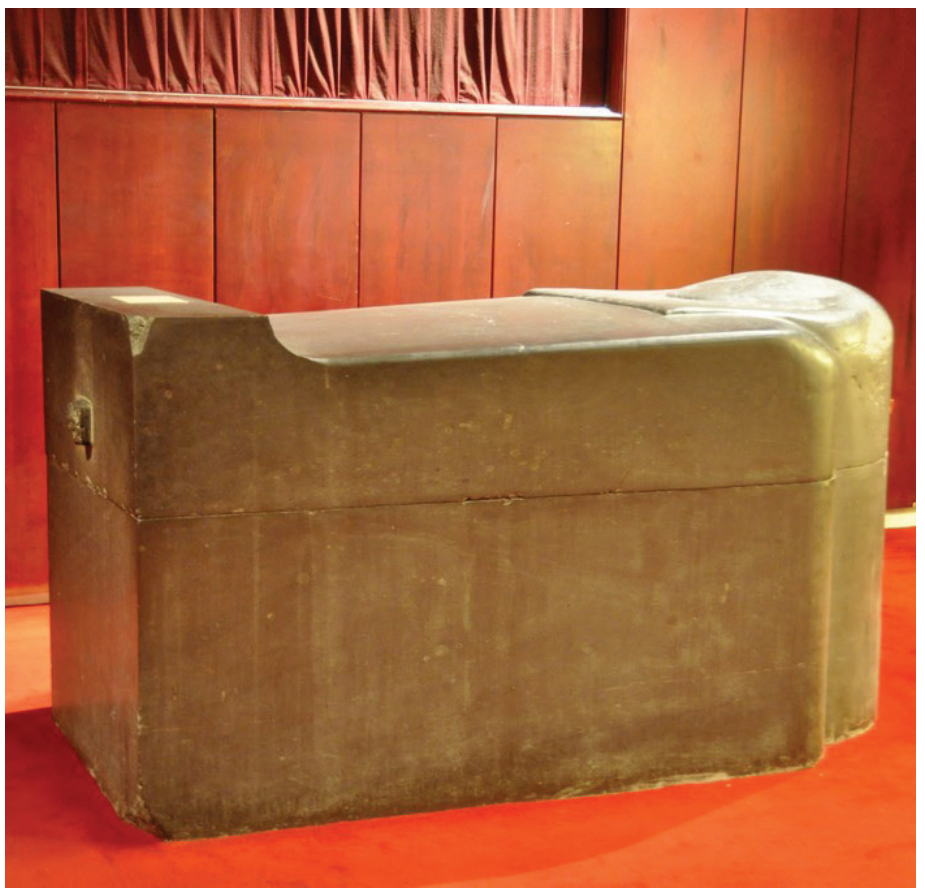

Figura 6: Sarcófago real de Sídon, cerca 600-500 a.C. Istambul, Museu Arqueológico (Arkeoloji Müzesi)

Fonte: https://www.livius.org/pictures/lebanon/saida-sidon/sidon-royal-tombs/ sidon-royal-tombs-chamber-1-egyptian-style-sarcophagus/ (Acesso em: 20/06/2021) 


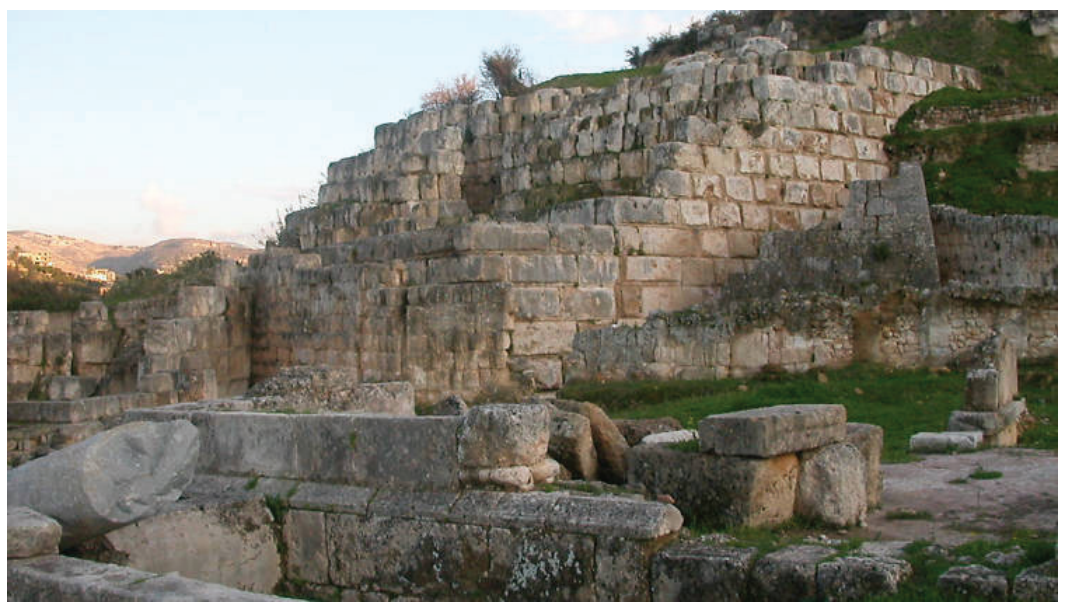

Figura 7: Vestígios materiais do templo de Eshmoun, Sídon.

Seculos VI-III a.C.

Fonte: https://www.timeout.com/beirut/travel/ancient-sidon (Acesso em: 20/06/2021)

A cidade foi, como Biblos, estabelecida sobre um promontório, dentro do modelo de assentamento típico dos fenícios, localizada entre Tiro e Berytos (Figs. 6 e 7). Arqueologicamente, temos um grande montículo que ao sul está rodeado por uma enseada e, ao norte por um porto. Entre os vestígios mais antigos da cidade temos um templo monumental datado de $c$. 1500 a.C. (KILLEBROW, 2019, p. 47).

Do período aquemênida, ou seja, da Idade do Ferro III, temos um sarcófago descoberto em Sídon. Ele tem sua identidade questionada. Seria de um sátrapa ou de um rei? Sabatino Moscati acreditava estarmos diante de uma representação do rei fenício (MOSCATI, 1976, p. 113). É datado de $c$. 440-430 a.C., confeccionado em mármore e possui comprimento de 2,8 m.

Mais dois sarcófagos foram encontrados na necrópole desta importante cidade fenícia, os quais junto ao altar decorado com esculturas de dançarinas e de divindades, do templo de Eshmun, seriam testemunhos, na opinião do arqueólogo Sabatino Moscati (1976, p. 114), do refinamento da corte real de Sídon.

O estudo de Josette Elay (2005) é a primeira e única biografia dedicada a um rei fenício. No caso, 'Abd'astart I de Sídon, que reinou de 365 a 352 a.C., período de domínio aquemênida. Este rei é conhecido por fontes gregas. ${ }^{24}$ Dentro da ideia já trabalhada neste artigo, da existência, de tempos

${ }^{24}$ Em seu decreto ateniense, o rei é descrito como "sendo um bom homem para o povo ateniense". Este decreto foi exibido na Acrópole de Atenas, para que qualquer pessoa que lesse grego pudesse lê-lo. Talvez seja por isso que Estraton é mencionado positivamente em várias fontes gregas que influenciaram a percepção desse rei até mesmo na historiografia moderna na Europa (ELAYI, 2005). 
em tempos, de cidades fenícias convergindo para si a atenção e controle da política externa, Sídon teria sido a cabeça de proa das cidades fenícias no período aquemênida, a Idade do Ferro III.

'Abd'astart I ficou conhecido por seu nome grego, Estraton, e como sendo um rei "fileleno". Josette Elayi (2005) demonstra como essa imagem, ainda que com raízes na própria Antiguidade, está mais ligada ao seu ressurgimento e recuperação na era moderna, condicionada pela descoberta da Fenícia no século XIX através de uma visão helenocêntrica. A pesquisa de Elayi, importante numismata e historiadora, nos apresenta um rei fenício, do século IV a.C., às portas do período helenístico, já carregando as características deste momento tão particular do mundo antigo. Assim, temos um rei refinado, culto, estético e eclético, aberto às culturas oriental e ocidental; enérgico e corajoso, tendo sido o primeiro rei fenício a se opor ao imperialismo persa.

Como coloca Astrid Nunn (2005, p. 1-2):

A famosa estátua de uma criança ("menino do templo") dedicada por Ba’alšillem, filho do rei Ba'ana, muito provavelmente representa o filho de Ba'alšillem, que não é outro senão 'Abd'aštart. O reinado de Ba'ana, sob o qual 'Abd'aštart viveu sua primeira infância, corresponde ao fim do reinado de Dario II e ao início do reinado de Artaxerxes e não parece ter sido muito agitado. Quando Ba'alšillem subiu ao trono, 'Abd'aštart tinha menos de 10 anos. A situação política se deteriora, Sídon deve fornecer sua cota de equipamento militar aos persas. Vinte e cinco a trinta e cinco anos depois, é sua vez de subir ao trono. O rei sidônio tem uma função guerreira e religiosa, política e diplomática contrabalançada por instituições cívicas. 'Abd'aštart era certamente um rei tradicional, tanto em suas funções quanto em sua aparência, conforme sua efígie aparece nas moedas. Por outro lado, os vestígios arqueológicos helenizantes de "Bustān ēš-Šêh" e o decreto ateniense atestam a existência de relações entre 'Abd'aštart e os gregos. Mesmo que os próprios monumentos gregos de Sídon não possam ser datados com precisão, eles certamente existiram sob 'Abd'aštart que, como outros reis sidônios, apreciava a forma e talvez o conteúdo grego. $\mathrm{O}$ fim de seu reinado foi marcado por uma revolta contra o domínio persa, motivada, entre outras coisas, por novos preparativos militares contra o Egito. Anuncia o período que se seguirá e que será um dos mais sombrios da história de Sidon no século IV a. C. (tradução livre nossa).

A linhagem real fenícia, em Sídon, é melhor conhecida em relação ao período aquemênida. Ainda assim, conhecemos Abdi-Milkuti, que teria reinado entre 685-677 a.C. sob Assarhaddon, da Assíria (ELAYI 2007).

Duas genealogias podem ser depreendidas: a da dinastia de Eshmunazor (séculos VI-início do V a.C.) e a de Baalshillem. ${ }^{25}$ Como resume Josette Elayi (2007, p. 5):

25 A documentação existente corresponde a cerca 32 inscrições, dois sarcófagos, os vestígios arquitetônicos do templo de Eshmoun, a cunhagem sidoniana do período e as fontes clássicas (ELAYI, 2007). 
O primeiro rei conhecido desta dinastia foi Eshmunazor, posteriormente conhecido como Eshmunazor I. Ele foi sucedido por seu filho Tabnit, que se casou com sua irmã Amoashtart. Como Tabnit morreu antes do nascimento de seu filho Eshmunazor II, a rainha-mãe (HMLKT) Amoashtart assumiu o interregno até o nascimento, depois a co-regência com seu filho durante sua infância. Depois disso, Eshmunazor II reinou sozinho. No final de seu reinado, ele foi sucedido por Bodashtart, que era filho de um irmão (ou irmã) de Tabnit e Amoashtart. Bodashtart provavelmente associou seu filho Yatonmilk, o príncipe herdeiro, ao poder governante, e possivelmente o sucedeu. (tradução livre nossa).

A segunda dinastia conhecida inicia-se com Baalshillem I, o qual foi sucedido por seu filho Abdamon, sucedido ele também por seu filho, Baana, sucedido por seu filho Baalshillem II (ELAYI, 2007). A famosa estátua do "menino do templo", mencionada acima, teria sido dedicada por Baalshillem II no templo de Eshmoun e representaria seu filho 'Abd'astart (Fig. 8) (ELAYI, 2007; NUNN, 2005). Como vimos acima, 'Abd'astart ficou conhecido como Estraton e teria reinado entre 365 e 352 a.C.

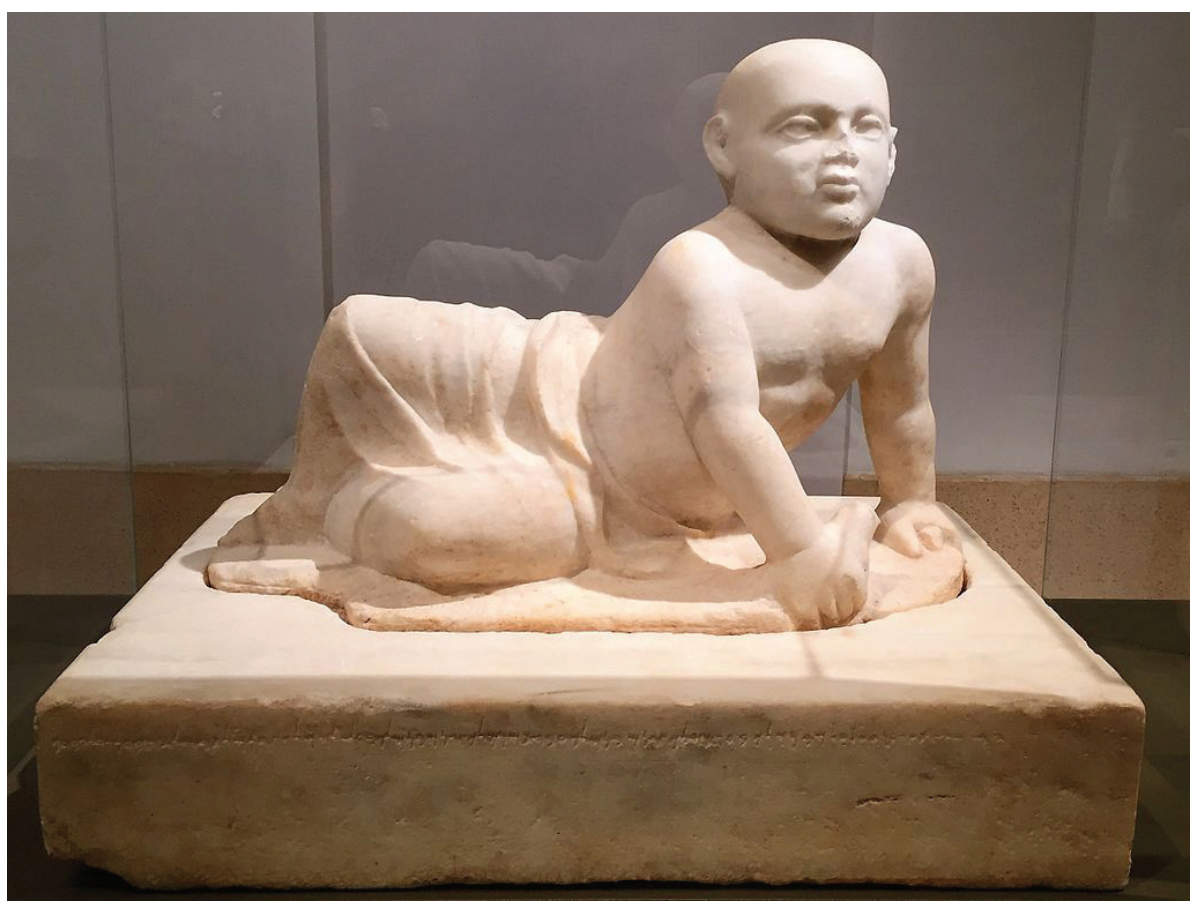

Figura 8: "menino do templo". Estátua escavada por M. Dunand nos anos '60 do século XX, próximo ao templo de Eshmoun. Traz uma inscrição em fenício que apresenta a dinastia de Baalshillem I.

Fonte: https://en.wikipedia.org/wiki/Baalshillem_Temple_Boy\#/media/ File:Votive_statue_from_eshmun.jpg (Acesso em: 20/06/2021) 
A cronologia da linhagem de Baalshillem foi estabelecida por Josette Elayi (2007, p. 9) a partir das emissões monetárias sidonianas:

Baalshillem II fez uma inovação muito importante: ele começou a inscrever em suas moedas as datas de emissão de acordo com os anos de seu reinado, a partir do ano 30, ou seja, 372 AEC [a.C.]. Isso significa que seu ano de ascensão foi 401 e que ele reinou até 366. Visto que todos os reinados seguintes são datados anualmente até 333, estabelecemos a cronologia absoluta em retrospecto, para o período 401-333. (tradução livre nossa).

Os últimos reis de Sídon não podem ser relacionados com a linhagem de Baalshillem com certeza; temos Tennes (351-347 a.C.), cujo nome é grego, não conhecemos seu nome fenício. Tennes foi executado pelos persas, os quais colocaram, em seguida, no trono de Sídon um rei apenas conhecido por nós a partir das legendas em suas moedas. Josette Elayi (2007, p. 9), apesar de salientar as dificuldades da documentação, acredita ser possível relacioná-lo ao rei cipriota Evagoras II, o qual teria reinado por apenas 4 anos e teria sido sucedido por Abdashtart II (342-333 a.C.). Ao conquistar Sídon, Alexandre, o Grande, o substituiu por Abdolonim.

\section{Estatuto real (Scnyzer)}

Na definição do seminal arqueólogo Enrico Acquaro (1987, p. 21-22):

Cada cidade fenícia constituía, do ponto de vista administrativo e político, uma entidade autônoma, com jurisdição sobre seu próprio território urbano e sobre a hinterlândia ao seu redor. [...] Na condução do governo citadino está o rei, que sobe ao trono usualmente por via hereditária. Seu poder é largamente autoritário e conectado a um 'legitimismo' eminentemente religioso. [...] A rainha possui uma certa autonomia, talvez como memória da concreta faculdade de ação política reconhecida ao elemento feminino nas cortes cananeias do II milênio [...] exercício do poder real deveria ter tramitações na corte: no entanto, esporádicas e pouco ilustrativas são as atestações diretas de sua existência, que consiste na menção, em Biblos de período assírio, de um organismo civil, um governador e um comandante militar. No âmbito das cidades individualmente, um conselho de anciãos apoia o rei no exercício do governo. Infelizmente, pouco sabemos acerca de quando foi introduzido e quais seriam suas prerrogativas: [...] em época persa, sobretudo, o poder monárquico e a vontade da maioria dos cidadãos constituíam, provavelmente, os dois polos fundamentais, ainda que dialéticos, nos quais se efetua a realeza institucional das cidades fenícias. ${ }^{26}$ (tradução livre nossa).

26 Acquaro (1987, p. 22) lembra, ainda, que em época assíria, devido à subjugação crônica das cidades fenícias teríamos a conexão de algumas cidades à autoridade real de um governador assírio. E este pesquisador lembra, igualmente, o caso da cidade de Simirra, visto acima, na qual a falta de uma instituição monárquica, levou a que a autoridade do governador fosse exercida diretamente. 
A reprodução desta passagem mostra como possuímos mais lacunas do que respostas em relação à organização sociopolítica das cidades fenícias orientais. Inferências, como a existência de cidades despojadas de um governo próprio, feitas com relação a Simirra, pelo fato desta ter recebido um governador assírio, conforme visto acima, ou acerca da existência de dois blocos, um Setentrional e um Meridional, com as respectivas cidades de cada bloco em certos momentos se alinhando com uma delas à frente, como o caso de Tiro defendido por Guy Bunnens, são hipóteses levantadas, mas para as quais possuímos dificuldade seja de corroborar, seja de negar.

Ainda assim, não podemos nos furtar a tentar produzir uma interpretação desse sistema monárquico, desta realeza. É o que nos propomos a apresentar a seguir.

O termo MLK designa rei no mundo semítico. No mundo assiro-babilônico é sarru, no Oeste-semítico MLK (milk em fenício-púnico; melek em hebreu; malka em aramaico; e, no mundo árabe, malik) (SZNYCER, 1984, p. 295).

Maurice Sznycer (1978, p. 565), em um artigo anterior, nos apresenta uma interpretação acerca do rei fenício:

[...] há uma diferença fundamental, já perceptível no final do $\mathrm{II}^{\circ}$ milênio, entre os reizinhos das cidades-estado fenícias e os monarcas absolutos do direito divino na Mesopotâmia, como também em Israel; um rei fenício, mesmo se o princípio da hereditariedade é respeitado, nada mais é, comumente, do que um primus inter pares, submetido às pressões das diversas camadas da população, não apenas aquela dos seus altos funcionários e conselheiros, ou aquelas das classes chamadas de 'superiores', representadas em um influente conselho, mas, por vezes, aquela do povo, que podia se agrupar em uma assembleia. (tradução livre nossa).

No livro dedicado a 'Abd'astart de Sídon, Josette Elayi (2005) afirma que as prerrogativas deste rei em relação à instituição monárquica, dizem respeito aos militares (ELAYI, 2005, p. 68-69), aos religiosos (p. 69-74) e e aos acordos diplomáticos (p. 74-75); mas um poder muito sólido e autoritário emerge ao lado deste soberano (p. 75: "O rei de Sídon estava longe de ser um monarca absoluto" - tradução livre nossa). Este poder paralelo era constituído por órgãos representativos ainda pouco conhecidos, mas certamente dotados de ampla autonomia. Assim, Sandro F. Bondì acredita ser bastante razoável concluir que esses corpos e não a monarquia da cidade são os verdadeiros oponentes do poder persa nas últimas convulsões da organização imperial antes da conquista macedônia definitiva (BONDİ, 2013, p. 151). 
Teríamos um conjunto de instituições, sobre as quais podemos perceber paralelos nas fundações além-mar, como por exemplo em Cartago (cf. SZNYCER, 1975-1977), tais como assembleias (Conselho dos Anciãos, Conselho dos Cem, Assembleia Popular), as quais exerceriam o poder junto aos reis.

No já mencionado "relato de Ounamon", vimos como Shekerbaal inicialmente se coloca como o detentor do controle sobre seu território e recursos, mas mais adiante no relato vemos igualmente aparecer comerciantes privados, pois esta categoria especial já estava formada e atuante no início do I milênio a.C. Quando da discussão que se desenvolve entre o rei e nosso personagem, há uma menção a estes novos agentes. Shekerbaal, irado, interpela Ounamon de sua necessidade de negociar diretamente com ele, o rei, já que havia outros empreendedores a quem ele poderia recorrer: "não há vinte navios de transporte, em meu porto, que possuo em sociedade com Smendes? E, no que diz respeito a Sídon, não tenho lá mais outros cinquenta navios em sociedade com Barkatel?” (BONDİ, 1995, p. 270).

Entre os séculos X e VI a.C., ${ }^{27}$ acredita-se, pois, que as trocas seriam controladas mais por aristocratas do que pela realeza. Uma evidência destes comerciantes-aristocratas seriam as grandes tumbas, datadas do século VII a.C., encontradas em localidades como Malta, Cartago, Almuñecar e Trayamar (GRAS; ROUILLARD; TEIXIDOR, 1988, p. 106; ALVAR EZQUERRA, 2008, p. 23-25). ${ }^{28}$

Como coloca Eleftheria Pappa (2019, p. 102):

Os fenícios, embora surgindo de um contexto socioeconômico do Oriente Próximo, não possuíam uma economia palaciana redistributiva do tipo assírio. Na Mesopotâmia e no Levante, o comércio privado, muitas vezes sobreposto ao comércio real, é documentado a partir da Idade do Bronze Final..... Embora uma distinção entre as esferas econômicas privadas e públicas não se aplique estritamente e existam sinergias entre atores estatais e privados, empresários em busca de lucro são documentados como agentes importantes da atividade econômica nas redes de comércio de longa distância da Idade do Bronze Final. (tradução livre nossa).

27 O século VI a.C. é marcado pela ascensão de Cartago como potência e controladora das rotas marítimas no Mediterrâneo Central, fato que é associado ao enfraquecimento das cidades fenícias do Oriente (KORMIKIARI, 2018).

28 Jaime Alvar Ezquerra salienta a centralização das atividades no palácio, ainda que abrindo espaço para a parceria do rei com a aristocracia. O ponto que ele mais reforça seria a impossibilidade de pensarmos em uma atividade gerada pelo 'empreendedorismo' de membros das camadas populares. 


\section{O exemplo de Cartago}

Teria havido um sistema político monárquico na maior e mais importante colônia fenícia, Cartago ${ }^{29}$ A política interna cartaginesa ainda nos é mal conhecida. Um ponto recorrente no debate é o questionamento acerca da existência de uma realeza em Cartago, ao menos no início de sua história.

O debate, durante um momento, ficou centrado nas figuras de G.-Ch. Picard e M. Sznycer, cada um defendendo posições teóricas antagônicas: a favor, no caso do primeiro, e contra, no caso do segundo. G.-Ch. Picard (1964) retoma um estudo anterior, para defender a tese de uma evolução interna, cartaginesa, da monarquia do direito divino para a democracia, passando por um estado aristocrático, com uma "monarquia magônida", de 550 a.C. até c. 370 a.C., em seguida uma "dinastia hanônida", até o trágico fim do "rei Bomilcar", que marcou, concomitante e precisamente, em outubro de 308 a.C., o fim da realeza púnica, ao menos enquanto expressão de um poder político, mas que, todavia, não desaparecera, pois as funções reais tornaram-se puramente honoríficas, apesar de "não deixarem traço algum na História" (PICARD, 1964, p. 169).

Em um artigo seguinte (PICARD, 1991), Picard manteve a defesa de suas ideias, utilizando-se, essencialmente, de Heródoto (XIII, 62, 4) e Diodoro da Sicília (XIII, 43, 5). No relato do primeiro a respeito da batalha de Himera, na Sicília, em 480 a.C., o general cartaginês Hamílcar não participa do confronto em si. Passa todo o tempo no acampamento cartaginês, orando e fazendo sacrifícios em prol do bom augúrio da expedição. $\mathrm{Na}$ opinião do historiador e arqueólogo, este é um fato praticamente único na História Antiga, e faz sentido apenas se interpretado à luz do conceito de um "rei-sacerdote". Por outro lado, Picard não nega a existência simultânea de outras instituições políticas cartaginesas: o sufetato, a Assembleia do Povo e o Conselho dos Cem. Dessa maneira, a teoria de G.-Ch. Picard, para a Cartago dos séculos VI a.C. ao IV a.C., comporta uma sociedade dividida entre um poder carismático e real, mas exclusivamente militar, e o poder dos sufetes, por seu lado, unicamente civil. A partir do século IV a.C., o rei cartaginês deixa de existir, mas Picard não aventa hipótese alguma para as razões dessa dissolução. De qualquer forma, o pesquisador reitera que esse poder real cartaginês esteve inicialmente ligado a uma única família, a dos Magônidas, fundada por Magon, no século VI a.C.

Renomado filólogo e historiador, especialista do mundo semítico, M. Sznycer argumenta que o termo MLK não consta em nenhuma das milhares

29 Retomamos, aqui, discussão apresentada em KORMIKIARI, 2000. 
de inscrições provenientes de Cartago ou de alguma cidade fenícia ou cartaginesa do Ocidente Mediterrânico (seja ela votiva, funerária, dedicatória, etc.), do período de domínio cartaginês. Paralelamente, com referência à língua púnica, possuímos centenas de menções, em inscrições distribuídas tanto no tempo (em Cartago são datadas, na sua maioria, do século IV e III a.C.) como no espaço, a um tipo específico de magistratura semítica: o sufetato. Este está presente desde o $\mathrm{II}^{\circ}$ milênio a.C., por exemplo, nos textos de Mari, no Eufrates e também no Antigo Testamento. A raiz TPY, transformada em SPT no alfabeto do oeste-semítico (com 22 letras), possuía um sentido mais amplo do que o de "julgar", como inicialmente se acreditou. Este sentido maior era o de "comandar", "governar", "exercer o poder". Os shoupetim (SPTM) fenícios e púnicos, e os shoftim hebreus não são meros juízes, e sim chefes, magistrados supremos. A justiça, com certeza, era uma de suas atribuições (SZNYCER, 1984, p. 294-95).

A uma informação negativa (inexistência da palavra MLK em inscrições púnicas), portanto, M. Sznycer acrescenta uma positiva (emprego absolutamente difundido da instituição do sufetato no mundo púnico ${ }^{30}$ ). Por outro lado, as fontes textuais gregas e latinas não se furtaram em assinalar a presença de "reis" em Cartago. Contudo, ao mesmo tempo que utilizaram termos como rex e basileus para designar os altos magistrados cartagineses (Políbio, Heródoto, Aristóteles, Diodoro da Sicília) ou mesmo mencionaram dois reis, como na citação de Cornélio Nepo (bini regis), estes mesmos autores fizeram uso de outras categorias políticas para citações de caráter análogo (ou seja, nas quais procuravam fazer algum tipo de referência ao alto comando cartaginês). São elas: arcontos (arconte), praetor, dux, imperator, dictator, consul (em geral no plural duplo: consules). Diante da impossibilidade de encontrar uma categoria política equivalente, entre o termo púnico SPTM e as instituições políticas gregas e romanas, a literatura latina optou, por fim, pela transcrição pura e simples do termo: sufes, plural: sufetes (SZNYCER, 1984, p. 293).

Cartago representa a primeira colônia fenícia, de fato, no Ocidente Mediterrânico. S. Lancel, mais recentemente, empreendeu a análise do mito de fundação (1992, p. 49-50). Na sua opinião, este mito estabelece entre Cartago e a metrópole, Tiro, uma relação de apoikia, sob a forma de uma cisão provocada por uma morte (realizada pelo rei Pigmalião contra o marido de Elissa, sua irmã). De acordo com o relato de Timeu, foram cidadãos (politai) que acompanharam Elissa. Na versão de Justino (IV, 15) aparece a palavra senatores (notáveis). Estamos diante de menções à aristocracia tíria. S. Lancel depreende, portanto, que Cartago já nasce dotada de uma estratificação

30 Sobre novas evidências do sufetato no Ocidente Mediterrânico, ver GUIRGUIS; IBBA, 2017. 
social completa. Outro momento do mito, que menciona o rapto das 24 virgens do templo de Vênus (Astarte?) em Chipre (Justino V, 4-5), garantiu o povoamento da nova cidade. Essa parte específica do relato, que pode ser comparada com a lenda do rapto das Sabinas (garantia do povoamento romano) fornece subsídios para a idealização de um esquema estrutural posto em uso em relatos do gênero. No entanto, a arqueologia comprovou que a ligação entre Cartago e Chipre se manteve constante ao longo dos séculos (BISI, 1965). Assim, S. Lancel crê que a passagem em questão revela uma verdadeira deductio, isto é, uma transferência de população politicamente organizada. Por fim, a ação dos sacerdotes de Melqart enquanto agentes intermediários dos contatos realizados entre as escalas marítimas e comerciais tírias e as populações locais, no Mediterrâneo Ocidental, aspecto da expansão marítima fenícia atualmente tido como fato pela historiografia moderna (ACQUARO, 1988, p. 187-89), encontra um paralelo na menção de Justino (IV, 5) aos sacra Herculis (os objetos litúrgicos do culto de Hércules que, no caso, devemos ler como Melqart), os quais Elissa teria levado consigo para a nova cidade. Desse modo, a exportação do culto de Melqart assegurou à colônia uma consagração religiosa.

Cartago foi, portanto, uma colônia oficial de Tiro, mas foi governada por uma aristocracia desde a sua origem. A realeza não existiu ali e podemos trabalhar com a ideia de que o sufetato, enquanto magistratura civil plena, constituiu a base de sua organização política.

\section{Conclusão}

Acreditamos que a existência de sociedades imperialistas como a egípcia, a assíria, a babilônica e a persa, as quais deixaram documentação que indica a sujeição, em graus variados, a depender do contexto em questão, das cidades fenícias, e deste modo, de suas casas reais, nos levam a realmente olhar para a monarquia fenícia como uma instituição mais fraca, ainda que tentativas de afirmação, como as inscrições de Abi-Baal e Eli-Baal, de Biblos, possam ser apresentadas.

A falta de narrativas internas acerca da organização sociopolítica destas cidades dificulta interpretações alternativas. Ao mesmo tempo, um ponto que nos chama a atenção diz respeito ao complexo e intricado processo de expansão marítima, que ao menos Tiro e Sídon empreenderam a partir dos séculos XI-X a.C., usualmente dividido em dois momentos, um de contatos mais esporádicos e o outro de consolidação com a fundação de novos assentamentos (cf. KORMIKIARI, 1993). A evidência apontada em nosso 
artigo, leva à crença da existência de uma parceria entre reis e aristocratas, uma divisão de poder que não deve ser compreendida de maneira leve. Este tipo de empreitada marítima era muito arriscada e demandava uma grande capacidade organizacional, não à toa, aponta-se uma parceria entre fenícios e micênicos nestas, na virada da Idade do Bronze para a Idade do Ferro, em relação à primeira etapa, de contatos esporádicos, com base em uma identificação palaciana, centralizadora (KORMIKIARI, 1993). O elemento aristocrata aparece, neste cenário, como parceiro e importante elo entre os centros orientais e os do Mediterrâneo ocidental e central. Vemo-lo ganhando cada vez mais força nas fundações fenícias que se seguem à fase dos contatos, a partir do século IX a.C., como procuramos demonstrar para o caso de Cartago.

Por fim, pesquisas arqueológicas vêm apontando a existência de trocas e mesmo de domínio sobre territórios interioranos e costeiros na região da siro-palestina por parte de Tiro e Sídon (por exemplo, LEHMANN, 2019; IAMONI, 2019; BERLIN; HERBERT, 2020), mas as bases administrativas destes, os graus de sujeição e resistência nos escapam. Com certeza, cabe à Arqueologia o incremento das discussões acadêmicas, aumentando nosso corpus documental de trabalho, o que pode levar a uma melhor compreensão da sociedade fenícia.

\section{Abreviaturas}

KAI - DONNER, H. e RÖLLIG, W. Kanaanäische und aramäische Inschriften. Mit einem Beitrag von O. Rössler. Wiesbaden I, 1966; II, 1968; III, 1969.

NAC - Numismatica e antichità classiche

PNA - RADNER, K e BAKER, H. (eds.) The Prosopography of the Neo-Assyrian Empire. Helsinki: The University of Helsinki.

RINAP - Royal Inscriptions of the Neo-Assyrian Period. Eisenbrauns; Penn State University Press.

SAA-State Archives of Assyria Bulletin

\section{Fonte escrita}

JUSTINO. Abrégé de l'Histoire Romaine. Paris: Libraire Garnier Frères, trad. de Maurice Rat. 


\section{Referências bibliográficas}

ACQUARO, E. Cartagine: un impero sul Mediterraneo. Archeologia 7. Roma: Club del libro fratelli Melita, 1987.

ACQUARO, E. Il tempio nella precolonizzazione fenicia. In: ACQUARO, E.; GODART, L.; MAZZA, F.; MUSTI, D. (eds.). Atti del Convegno Internazionale, Roma, 14-16 marzo, 1985. Academia Belgica, Istituto per la Civiltà Fenicia e Punica (Collezione di Studi Fenici, 28). Roma: Consigli Nazionale delle Ricerche, 1988, p. 187-189.

ALVAR EZQUERRA, J. Modos de contacto y medios de comunicación: los orígenes de la expansión fenicia. In: CELESTINO, S.; RAFEL, N.; ARMADA, X.-L. (eds.). Contacto cultural entre el Mediterráneo y el Atlántico (siglos XII-VIII ane). La precolonización a debate. Madrid: CSIC, Escuola Española de Historia y Arqueología en Roma, 2008, p. $19 \square 26$.

AUBET, M. E. The Phoenicians and the West. Politics, colonies and trade. Cambridge: Cambridge University Press, 2001.

BERLIN, A. M. e HERBERT, S. C. The Achaemenid-Ptolemaic transition. The view from southern Phoenicia. In: HONIGMAN, S.; NIHAN, Ch.; LIPSCHITS, O. (eds.). Times of transition: Judea in the Early Hellenistic Period. Mosaics, studies on ancient Israel, n. 1. Tel Aviv; Winona Lake: The Institute of Archaeology of Tel Aviv University; Eisenbraus, 2020, p. 143-159.

BISI, A. M. KUPRIAKA. Contributi allo studio della componente cipriota della civiltà punica. Roma: Gerardo Casini Editore, 1965.

BLOCH-SMITH, E.; NAKHAI, A. A landscape comes to life. Near Eastern Archaeology, Chicago, v. 62, n. 2, p. 62-127, 1999.

BONDİ, S. F. The origins in the East. In: MOSCATI, S. (ed.). The Phoenicians. Londres: Ib Tauris, 2011, p. 23-29. [1. ed. 1988]

BONDİ, S. F. Le comerce, lés échanges, l'économie. In: KRINGS, V. (ed.). La civilisation phénicienne et punique. Manuel de recherche. (Handbook of Oriental Studies). Leiden: E. J. Brill, 1995, p. 269-281.

BONDİ, S. F. Assetti istituzionali, politici e amministrativi nel mondofenicio e punico: aggiornamenti e nuove prospettive. In: ARRUDA, A. M. (Ed.). Fenícios e púnicos, por terra e mar. Actas do VI Congresso Internacional de Estudos Fenícios e Púnicos, I. Lisboa, 2013, p. 149-156.

BONNET, C. Melqart. Cultes et mythes de l'Héraclès tyrien en Méditerranée, Studia Phrenicia, Louvain-Namur, v. VIII, 1988.

BONNET, C. I Fenici. Roma: Carocci, 2004.

BOSCHLOOS, V. Belgian archaeologists in Tyre (Lebanon): UNESCO Heritage, Phoenician Seals and Ancient Curses. Royal academy of overseas sciences. First young researchers overseas' day 16 December 2014, Bruxelas, 2016.

BUNNENS, G. Phoenicia in the later Iron Age. Tenth century BCE to the Assyrian and Babylonian periods. In: LÓPEZ-RUIZ, Carolina; DOAK, Brian (eds.). The Oxford Handbook of the Phoenician and Punic Mediterranean. Oxford: Oxford University Press, 2019, p. 57-74.

CAMINOS, R. A. A tale of woe: from a Hieratic Papyrus in the A. S. Pushkin Museum of Fine Arts in Moscow. Oxford: Griffith Institute, Asmolean Museum, 1977. 
CRAWLEY QUINN, J. In search of the Phoenicians. Princeton: Princeton University Press, 2018.

DUNAND, M. Byblos. Beirute: Librairie Adrien-Maisonneuve, 1973. [1. ed. 1968]

ELAYI, J.; ELAYI, A. G. Abbreviations and numbers on Phoenician pre-alexandrine coinages: the Sidonian example. NAC, v. 17, p. 27-36, 1988.

ELAYI, J. 'Abd'štart Ier/Straton de Sidon: un roi phénicien entre Orient et Occident. Paris: Gabalda, 2005.

ELAYI, J. Un updated chronology of the reigns of Phoenician kings during the Persian Period (539-333 BCE). Transeuphratène, v. 32, 2007.

ELAYI, J. Histoire de la Phénicie. Paris: Perrin, 2013.

ELAYI, J. Rib-Hadda, le roi de Byblos qui ne ment pas. Journal Asiatique, Louvain, v. 302, n. 2, p. 377-399, 2014.

FALES, F. M. Phoenicia in the Neo-Assyrian Period. State Archives of Assyria. Bulletin, vol. XXIII, 2017, p. 181-295.

FINKELSTEIN, I.; ARIE, E.; MARTIN, M. A. S.; PIASETZKY, E. New evidence on the late Bronze/Iron I transition at Meggido: implications for the end of the Egyptian rule and the appearance of Philistine pottery. Agypten und Levant/Egypt and the Levant, v. 27, p. 261-280, 2017.

FLORENZANO, M. B. Entre reciprocidade e mercado: a moeda na Grécia Antiga. Tese de Livre-Docência defendida do Museu de Arqueologia e Etnologia da Universidade de São Paulo, 2000.

GRAS, M.; ROUILLARD, P.; TEIXIDOR, J. L'univers phénicien. Paris: Arthaud, 1989.

GUIRGUIS, M.; IBBA, A. Riflessioni sul sufetato tra Tiro, Cartagine e Roma. Nuovi documenti da Sulky (Sardegna) e Thugga (Tunisia). In: EVANGELISTI, S.; RICCI, C. Le forme municipali in Italia e nelle province ocidentali tra $i$ secol I a.C. e III d.C. Atti dela "XXI Rencontre franco-italienne sur l'epigraphie du monde romain" (Campobasso 24-26 settembre 2015). Bari: Edipuglia, 2017, p. 193-218.

HODOS, T. The Archaeology of the Mediterranean Iron Age. Cambridge: Cambridge University Press, 2020.

IAMONI, M.; HAIDER, M.; TURRI, L.; SIMI, F. The northern Lebanon Project: archaeological survey of the plain of Koura and the Province of Tripoli. First Season report. Bulletin d'Archéologie et d'Architecture Libanaises (BAAL), v. 19, p. 147-172, 2019.

KALLALA, N.; FENTRESS, E.; QUINN, J.; WILSON, A. Survey and excavation at Utica 2010. Papers at the British School at Rome, novembro, p. 1-33, 2010.

KANIEWSKI, D.; GUIOT, J.; VAN CAMPO, E. Drought and societal collapse 3200 years ago in the Eastern Mediterranean: a review. WIREs Clim Change, p. 1-14, 2015.

KILLEBREW, A. E. Canaanite roots, proto-Phoenicia, and the early Phoenician Period. Ca. 1300-1000 BCE. In: LÓPEZ-RUIZ, C.; DOAK, B. R. (eds.) The Oxford Handbook of Phoenician and Punic Mediterranean. Oxford: Oxford University Press, 2019, p. 39-55.

KOKKINOS, N. Tyrian Annals and ancient Greek chronography. Scripta Classica Israelica. Yearbook of the Israel Society for the promotion of Classical Studies, v. XXXII, 2013, p. 21-66. 
KORMIKIARI, M. C. N. Expansão marítima e influência cultural fenícia no Mediterrâneo centro ocidental. Anais da VII Reunião Anual da SBEC (Sociedade Brasileira de Estudos Clássicos). Araraquara, 1993, p. 261-267.

KORMIKIARI, M. C. N. Norte da África autóctone do século III ao I a.C.: as imagens monetárias reais berberes. Tese de doutorado. Faculdade de Filosofia, Letras e Ciências Humanas Museu de Arqueologia e Etnologia, Universidade de São Paulo, São Paulo, 2000.

KORMIKIARI, M. C. N. O comércio, as trocas e o sistema do dom entre os fenícios. In: CARVALHO, A. G (org.) Interação social, reciprocidade e profetismo no mundo antigo. Vitória da Conquista: Ed. UESB, 2004, p.127-154.

KORMIKIARI, M. C. N. O conceito de cidade no mundo antigo e seu significado para o Norte da África berbere. In: FLORENZANO, M. B. B.; HIRATA, E. V. (orgs.). Estudos sobre a cidade antiga. São Paulo: Edusp; Fapesp, 2009, p. 137-172.

KORMIKIARI, M. C. N. Fenícios pelo Mediterrâneo: formas de contato diversificadas. Cadernos do Lepaarq, v. XV, n. 29, p. 174-185, 2018.

KORMIKIARI, M. C. N. Quem eram os fenícios? Ou da crise identitária na Academia do século XXI. Hélade, Niterói, v. 5, n. 2, p. 13-34, 2019.

LANCEL, S. Carthage. Paris: Libraire Arthème Fayard, 1992.

LEHMANN, G., Archaeology and Material Culture of Phoenicia and the Phoenicians. Oxford: Oxford Bibliographies, Biblical Studies, 2019.

LIVERANI, M. Antico Oriente. Storia, societá, economia. Roma; Bari: Laterza, 2004. [1. ed. 1988]. LÓPEZ-RUIZ, C.; DOAK, B. R. (eds.). The Oxford Handbook of Phoenician and Punic Mediterranean. Oxford: Oxford University Press, 2019.

MARINER, N.; MORHANGE, Ch.; CARAYON, N. Ancient Tyre and its harbours: 5000 years of human-environment interactions. Journal of Archaeological Science, v. 35, p. 1281 1310, 2008.

MATA, D. R. Gadir, su estructura plural. Un modo de ver su fundación fenicia en el espacio y en el tiempo. Revista Onoba, Huelva, n. 6, p. 249-288, 2018.

MATTHiAe, G. S. Art et politique: les images des Pharaons à l'étranger. Ägypten und Levant/Egypt and the Levant, v. 10, p.189-196, 2000.

MAUSS, M. Sociologia e antropologia. 2 vols. São Paulo: E.P.U.; Edusp, 1974.

MOSCATI, S. Problematica della civiltà fenicia. Roma: Consiglio Nazionale delle Ricerche, Studi Semitici, n. 46, 1974.

MOSCATI, S. I fenici. Milão: Rizzoli Editore, 1976.

MOSCATI, S. Chi furono i fenici. Turim: SEI, 1992.

NUNN, A. Josette Elayi, «'Abd'aštart Ier/Straton de Sidon: Un roi phénicien entre Orient et Occident. Supplément n ${ }^{\circ} 2$ à Transeuphratène, 2005, 191 p., 5 pl. et 2 cartes», Abstracta Iranica [En ligne], Volume 28, 2007, document 81, mis en ligne le 18 septembre 2007, consulté le 30 juin 2021. URL: http://journals.openedition.org/abstractairanica/15642; DOI: https://doi.org/10.4000/abstractairanica.15642

PAPPA, E. The poster boys of Antiquity's “capitalism” shunning money? The spread of the alphabet in the Mediterranean as a function of a credit-based, maritime trade. Revista do Museu de Arqueologia e Etnologia, São Paulo, v. 33, p. 91-138, 2019. 
PEDRAZZI, T. Fingere l'identitá: confini e culture materiale in Oriente. Rivista di Studi Fenici, Roma, v. 40, n. 2, p. 137-157, 2012.

PICARD, G.-Ch. Les sufètes de Carthage dans Tite-Live et Cornelius Nepos. Revue des Études Latines, 41, p. 269-281, 1964.

PICARD, G.-Ch. Le pouvoir suprême à Carthage. Studia Phcenicia, Louvain-Namur, v. VI, OLA 26, p. 119-124, 1987.

RAMAZZINA, A. A. Organização do espaço e território na Fenícia na Idade do Ferro: cidades e necrópoles. Mare Nostrum, São Paulo, v. 3, n. 3, p. 157-174, 2012.

SADER, H. The archaeology of the Phoenician cities. In: LÓPEZ-RUIZ, C.; DOAK, B. R. (eds.) The Oxford Handbook of Phoenician and Punic Mediterranean. Oxford: Oxford University Press, 2019, p. 125-138.

SADER, H. The History and Archaeology of Phoenicia. Atlanta: SBL Press, $2019 \mathrm{~b}$.

SCHMITZ, Ph. C. Research Tools. In: LÓPEZ-RUIZ, C.; DOAK, B. R. (eds.) The Oxford Handbook of the Phoenician and Punic Mediterranean. Oxford: Oxford University Press, 2019, p. 9-22.

SZNYCER, M. L' «Assemblée du peuple» dans les cités puniques d'après les témoignages épigraphiques. Semitica, v. XXV-XXVII, 1975-1977, p. 47-68.

SZNYCER, M. Carthage et la civilization punique. In: NICOLET, Cl. (org.) Rome et la conquête du monde méditerranéen. Tome 2: Genèse d'un empire. (Nouvelle Clio). Paris: PUF, 1978, p. 545-593.

SZNYCER, M. Le probléme de la royauté dans le monde punique. Bulletin Archéologique du Comité des Travaux Historiques. Paris, Nouvelle Série, v. 17, B, p. 291-301, 1984.

VAN DOMMELEN, P. Colonialism and migration in the ancient Mediterranean. Annual Review of Anthropology, v. 41, p. 393-409, 2012.

VAN DONGEN, E. "Phoenicia": naming and defining a region in Syria-Palestine. In: ROLLINGER, R.; GUFLER, B.; LANG, M.; MADREITER, I. (eds.). Interkulturalität in der Alten Welt. Vorderasien, Hellas, Ägypten und die vielfältigen Ebenen des Kontakts. Wiesbaden: Harrassowitz Verlag, , 2010, p. 471-488.

WAGNER, C. G. Santuarios, territorios y dependencia en la expansión fenicia arcaica en Occidente. Arys, v. 3, p. 41-58, 2000. 